\title{
Kesinambungan Akidah al-Ash'ari terhadap Pendekatan Salaf al-Salih dalam Persoalan Sifat
}

\author{
Continuity of al-Ash'ari's Creed to the Salaf's Approaches in Divine Attributes
}

MOHD HAIDHAR KAMARZAMAN ${ }^{1}$

\begin{abstract}
Imam al-Ash'ari, a prominent Muslim theologian, has contributed significantly to the development of the Sunnite creed. His approach of using reason in defending Islamic theology has put a strong and solid foundation in facing the challenge of the Muslim enemies. However, many have questioned al-Ash'ari as a continuation to the Salaf's teachings especially from those who are against the use of reason as a methodology in Islam. They have labeled him and his school of thought as deviated from the true path of the Salaf and brought about new creed, especially in the problem of Divine's Attributes, afar from the Salaf's creed such as the Shi'ite, Mu'tazilite and others. This research aims at studying and evaluating whether there is continuity of thought in alAsh'ari with the thought of the Salaf in the problem of Divine Attributes. It also attempts at studying the similarities and differences in al-Ash'ari's and the Salaf's thoughts in the problem of Divine Attributes. In general, the research employs qualitative methods including data collection, content analysis, comparative analysis, historical-based analysis methods. The result of the study shows that there is a prominent continuation in al-Ash'ari methodology with the Salaf's methodology in verifying the Islamic doctrines. The continuity of thought can also be found in the issues discussed by al- Ash'ari especially pertaining to Divine Attributes.
\end{abstract}

Keywords: al-Ash'ari, Divine Attributes, Islamic creed, Kalam, salaf al-salih

Salaf merupakan satu istilah yang lazim digunakan dalam suasana ilmiyyah seperti yang termaktub dalam-kitab-kitab dan buku-buku karya ulama akidah. Secara bahasanya istilah Salaf merujuk kepada orang yang mendahului dari kalangan bapa-bapa dan kaum kerabat ke atas, iaitu mereka yang mendahului dalam kebaikan. Mereka merupakan generasi yang terawal dari kalangan Tabi'in disebut sebagai Salaf al-Salih (Ibn Manzur n.d: 2068). Allah berfirman (Surah al-Zukhruf:55-56) yang bermaksud:

Setelah mereka menyebabkan kemurkaan Kami (dengan perbuatan derhaka itu), Kami menyeksa mereka, Iaitu menenggelamkan mereka semuanya di laut (sehingga binasa). Maka Kami jadikan mereka contoh dan pengajaran bagi orang-orang yang datang kemudian.

${ }_{1}^{1}$ Mohd Haidhar Kamarzaman, Ph.D., senior lecturer at Centre for Aqidah and Global Peace, Faculty of Islamic Studies, Universiti Kebangsaan Malaysia, 43600 BANGI, Selangor, Malaysia, email: haidhar@ukm. edu. my.

https://doi.org/10.24035/ijit.16.2019.007 
Manakala dari sudut istilah pula, sebahagian besar ulama mu'tabar merujuk kepada konteks masa iaitu tiga kurun yang terawal. Menurut al-Athari, apabila disebutkan Salaf maka disisi ulama akidah, ianya merujuk kepada takrif bagi Sahabat sahaja, atau Sahabat dan Tabi'in, atau Sahabat, Tabi'in dan Tabi' Tabi'in dari kurun yang terbaik iaitu tiga abad yang terawal. Mereka adalah golongan yang telah diketahui dan disaksikan ke atas mereka ini dengan kepimpinan (imamah) mereka, kelebihan mereka, ketaatan mereka dalam mengikuti Sunnah, penghindaran dan penolakan mereka dari perkara bidah, dan mereka juga adalah golongan yang telah disepakati ummah tentang imamah mereka, keagungan taraf mereka dalam agama. Kerana inilah dinamakan pada mereka ini iaitu golongan terawal dengan Islam (al-Athari 1422H: 15). Istilah Salaf juga boleh disebut sebagai golongan yang hidup dalam kurun yang terbaik dimana telah dinaskan oleh Rasulullah dari riwayat al-Bukhari tentang mereka ini dalam sabdanya (al-Bukhari 1987: 1335) yang bermaksud:

"Sebaik baik manusia ialah orang yang sezaman dengan saya (para shahabat) kemudian generasi yang mengikuti mereka (para Taabi iin) kemudian generasi yang mengikuti mereka dengan baik (Atbaa`ut Taabi'iin), kemudian datang satu kaum dimana persaksian mereka mendahului sumpahnya dan sumpah mereka mendahului persaksiannya."

Manakala al-Ash ${ }^{\mathrm{c}}$ ari pula adalah seorang ulama Ahli Sunah Waljamaah yang lahir sekitar abad ke-3 Hijrah yang meneruskan apa yang dibawa oleh para ulama Salaf terdahulu. Beliau meneruskan manhaj akidah yang telah dibawa oleh para ulama Salaf sehingga mampu untuk bangkit menentang fahaman yang sesat dan menyeleweng pada zamannya. Nama sebenar beliau adalah Ali bin Ismail bin Abi Bishr bin Salim bin Ismail bin Abdullah bin Musa bin Bilal bin Abi Burda bin Abi Musa al-Ash'ari (McCarthy 1953: 139). Beliau digelar sebagai Abu Hasan al-Ash'ari sebagai nisbah kepada datuknya iaitu Abu Musa al-Ash'ari (Ibn Asakir 1347H: 146). Menurut jumhur ulama al-Ash'ari dilahirkan pada tahun 260 Hijrah (Ibn Asakir 1347H: 146; al-Subki 1918: 247). Beliau dilahirkan di Basrah tetapi menetap di Baghdad dan wafat di sana (McCarthy 1953: 139). Para ulama berselisih pandangan terhadap tarikh kewafatan beliau. Menurut Ibn Kathir beliau wafat sekitar tahun 330 lebih Hijrah (Ibn Kathir 1966: 187). Menurut al-Asadi beliau wafat pada tahun 320 Hijrah (McCarthy 1953: 140). Menurut Ibn Furak (Ibn Asakir 1347H: 39), Ibn Hazm (McCarthy 1953: 140) dan Abu al-Fallah Abd al-Harr bin Ibn al-'Imad al-Hanbali (1989: 129) pula beliau wafat pada tahun 324 Hijrah bersamaan dengan tahun 936 Masihi.

\section{Ketepatan antara Manhaj Salaf Salih dan al-Ash'ari dalam Mengisbatkan Akidah}

Sebelum dibahaskan tetap analisis kesinambungan dalam masalah sifat, perlu terlebih dahulu perlu diperhatikan kesinambungan dari sudut manhajnya. Ini kerana dengan manhaj sahaja yang boleh menentukan fahaman yang dibawa oleh satu-satu kumpulan. Manhaj yang dibawa oleh al-Ash'ari merupakan manhaj yang berkesinambungan berdasarkan dari manhaj Salaf yang hidup sebelum zaman al-Ash'ari. Manhaj yang dipegang atau dibawa oleh ulama Salaf merupakan manhaj yang disepakati oleh kesemua ulama Salaf termasuk dari kalangan mereka adalah Sahabat dan Tab'in. Manhaj ini adalah manhaj yang diikuti oleh kesemua ulama Salaf dan ianya tidak lari ruh al-Quran dan Sunnah. al-Ash'ari pula merupakan antara pelopor utama aliran Salaf dari sudut manhajnya. Malah beliau menyebut pula Imam Ahmad sebagai antara orang yang utama diikuti manhajnya. Bagi al-Ash'ari segala apa yang diriwayatkan dan dii'tiqadkan oleh ulama' Salaf, kesemuanya juga dii'tiqadkan oleh beliau tanpa ragu kerana golongan Salaf lebih memahami terhadap al-Quran dan 
Sunnah berkat kehampiran mereka dengan Rasulullah s.a.w terutamanya dari kalangan para Sahabat. Apa yang ditinggalkan oleh ulama salaf, itulah juga ditinggalkan oleh beliau tanpa ragu.

Al-Nashshar (1977: 276) juga pernah menyebut mengenai hampirnya manhaj al-Ash'ari terhadap manhaj Imam Ahmad terutamanya dalam penentangan al-Ash'ari dalam hampir kesemua masalah akidah golongan Muktazilah. Menurut al-Nashshar lagi, ketepatan manhaj al-Ash'ari dengan Imam Ahmad terzahir dalam penulisan beliau iaitu kitab Maqalat al-Islamiyyin yang sangat sempurna persamaannya dengan pandangan Imam Ahmad. Malah penggunaan metode qiyas Imam Ahmad juga menepati ciri yang qiyas 'aqli yang juga digunakan Imam Ahmad dalam perdebatannya. Begitu juga manhaj yang dibawa oleh Ibn Kullab dan al-Qalansi yang beraliran Kullabiyyah. AlAsh'ari juga banyak memuji Ibn Kullab (Salaf) dalam beberapa penulisannya termasuk mengambil sebahagian dari pemikiran akidahnya terutamanya dalam masalah sifat. Jikalau dilihat dalam kitab Maqalat karya al-Ash'ari, beliau seringkali memetik pendapat Ibn Kullab lalu dijadikan juga sebahagian dari pendapatnya. Contohnya petikan beliau mengenai isu sifat menurut pandangan Ibn Kullab (al-Ash'ari 1950: 202).

"Sesungguhnya Allah SWT sejak azali bersifat dengan hidup, mengetahui, berkuasa, mendengar, melihat..."

Dari pendedahan manhaj Salaf dan al-Ash'ari telah membuktikan ketepatan manhaj yang dibawa oleh al-Ash'ari terhadap manhaj Salaf menunjukkan kesinambungan yang dipegang oleh alAsh'ari. Manhaj al-Ash'ari bermula dari manhaj yang pertama sehingga yang keempat bertepatan dengan manhaj pertama ulama Salaf. Pertamanya manhaj al-Ash'ari adalah mendahulukan Nas melebihi sesuatu yang lain dan menolak penggunaan selain daripada Nas didahulukan dalam semua permasalahan akidah (al-Ash'ari 1977: 111). Kemudian keduanya ketika mahu mentafsirkan al-Quran pula, urutan penggunaan tafsiran menurut al-Ash'ari adalah bermula dengan al-Quran kemudian seandainya tiada dalam al-Qur'an baharulah dipindahkan kepada Sunnah. Jika tidak terdapat dari Sunnah baharulah dipindahkan kepada ijma' (al-Ash'ari 1977:122, 125, 127). Manhaj ini juga telah digunakan ulama Salaf dalam perbahasan mereka mengenai akidah sebagaimana yang telah dijelaskan sebelum ini (al-Ash'ari 1977: 122).

Berdasarkan ke empat manhaj al-Ash'ari ini, al-Ash'ari dan Salaf bersepakat menepati keempat-empat manhaj ini iaitu memberikan keutamaan terhadap wahyu berbanding akal dalam semua permasalahan akidah. Bagi al-Ash'ari dan Salaf, akal manusia ini merupakan sesuatu yang terbatas dan ianya tidak mampu untuk menggarap sebahagian perkara seperti masalah sam'iyyat melainkan didatangkan wahyu padanya. Walaubagaimanapun al-Ash'ari dan Salaf berittifaq bahawa akal merupakan sesuatu yang tidak bertentangan dengan Nas dan kedua-dua mereka menzahirkan penggunaan akal sesudah datangnya Nas ataupun ketika permasalahan tersebut tidak disentuh oleh Nas sama ada dari al-Quran mahupun Sunnah. Manhaj ini juga merupakan manhaj yang disepakati oleh kesemua ulama Salaf termasuk dari kalangan mereka adalah Imam Ibn Abbas yang menggunakan akal sesudah naql untuk mentafsir, Imam Abu Hanifah yang merupakan Ahl alRa'y, Imam Ahmad bin Hanbal dan Imam Shafi'i sebagai Mutakallimin, dan Imam-Imam Muktabar yang lain. Menurut Sulaiman Yassin (1997: 123) hakikat manhaj aqli dan naqli ini merupakan hakikat yang menepati manhaj yang disepakati dalam al-Quran ketika mengisbatkan akidah. Walaubagaimanapun keutamaan tetap diletakkan terhadap Nas dahulu baharulah kemudiannya berpindah kepada akal. Ini dapat dilihat jelas melalui pengiktirafan al-Quran terhadap manhaj aqli kerana akidah yang benar adalah akidah yang berasaskan kebenaran dan bukan berasaskan suatu sangkaan dan khayalan, keraguan dan kesangsian, atau ikut-ikutan serta taqlid, malah jauh sekali dari sebarang paksaan untuk mengikuti akidahnya. Akidah Islam yang mengiktiraf dua manhaj ini 
menolak manhaj yang digunakan oleh golongan Kristian terhadap penganutnya yang melarang untuk berfikir, bertanya atau mempersoalkan tentang i'tiqad mereka.

Manhaj al-Ash'ari yang kelima pula adalah, al-Ash'ari dan Salaf juga kesemuanya bersepakat bahawa pandangan para Sahabat dan Ijma' mereka diraikan dari kesemua sudut (al-Ash'ari 1977: 127). Ini kerana mereka memiliki keutamaan yang langsung tidak dimiliki oleh orang lain kerana mereka merupakan orang yang belajar dan mengambil ilmu dari Rasulullah s.a.w. Segala riwayat dari mereka diambil kira sebagai satu pandangan yang terpenting sesudah al-Qur'an dan Sunnah.

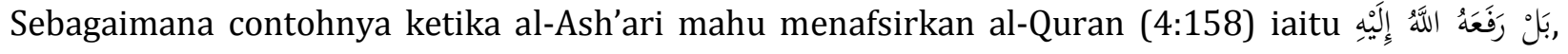
beliau menafsirkannya dengan mengambil pandangan ijma' yang menyebut: 'Ulama telah berijma' bahawasanya Allah s.w.t mengangkat Isa a.s naik ke langit” (al-Ash'ari 1977: 127).

Manhaj al-Ash'ari yang keenam disebutkan bahawa, al-Ash'ari dan semua ulama Salaf juga bersepakat bahawa al-Quran diperlakukan di atas makna zahirnya (al-Ash'ari 1977: 127). Tidak boleh memindahkan suatu makna dari lafaz al-Quran melainkan didatangkan dengan makna zahirnya. Walaubagaimanapun al-Ash'ari dan Salaf tetap bersepakat bahawa seandainya didatang bukti dan hujah yang kukuh yang merujuk kepada perpindahan makna dari makna yang zahir tersebut maka perlu dipindahkan. Ini banyak juga dilakukan oleh kalangan ulama salaf seperti Ibn Abbas sebagai mufassirin dan juga Imam Ahmad sebagai Mutakallimin. Sebagai contohnya, Ibn Abbas r. a pernah memindahkan makna dari surah al-Dhariyat (51: 47), maksudnya:

Dan langit itu Kami dirikan dengan kekuasaan Kami (dalam bentuk binaan yang kukuh rapi) dan sesungguhnya Kami adalah mempunyai kekuasaan yang luas tidak terhingga.

Ibn Abbas Mujahid, dan Qatadah, memindahkan makna يد dengan maksud قوة iaitu kekuasaan yang memberi maksud bahawa "Dan Langit itu Kami bangunkan dengan kekuasaan Kami". Walaupun pada zahir kalimah itu menunjukkan lafaz tangan, tetapi ia memberi maksud kekuasaan pada Allah s.w.t yang membangunkan langit dengan kekuasaan-Nya (al-Tabari 2009: 1028).

Selain itu juga, dalam manhaj al-Ash'ari yang ketujuh, al-Ash'ari dan Salaf juga bersepakat di atas manhaj yang mengambil serta meraikan kaedah bahasa Arab beserta uslubnya tidak kira dari sudut mantiqnya, balaghahnya, qawaidnya dan sebagainya yang melibatkan bahasa Arab kesemuanya diambil kira. Ini adalah kerana bagi al-Ash'ari dan Salaf, Bahasa Arab merupakan bahasa yang diturunkan oleh Allah pada al-Quran sebagai bahasa perantaraannya dan tidak ada bahasa lain yang mampu memahami al-Quran selain dari bahasa yang ia diturunkan. Tidak kira sama ada dari sudut usul bahasa mahupun juga makna lafaz dalam kaedah penggunaannya, ia diambil kira ketika mana mengisbatkan akidah. Kaedah ini disepakati oleh al-Ash'ari dan Salaf dan sememangnya dalam banyak isu akidah yang diisbatkan oleh al-Ash'ari, hampir kebanyakannya alAsh'ari berhujah berdasarkan kaedah bahasa Arab. Begitu juga dengan sebahagian ulama Salaf yang mengisbatkan beberapa isu akidah menggunakan kaedah bahasa Arab sebagaimana yang pernah juga dilakukan oleh Imam Ahmad dalam masalah Khalq al-Quran (al-Ash'ari 1977: 128).

Manhaj yang seterusnya disepakati juga dari kalangan ulama dan al-Ash'ari adalah meraikan asbab nuzul satu-satu ayat al-Quran dan asbab wurud satu hadith sebagai salah satu dari manhaj beliau. Bagi al-Ash'ari dan Salaf asbab nuzul dan asbab wurud memainkan peranan penting kerana ia boleh menentukan hukum yang masih lagi sabit atau pun tidak. Ia juga memainkan peranan bagi nasakh dan mansukh untuk melihat sama ada satu-satu hukum masih lagi disyariatkan atau pun telah dibatalkan syariatnya (al-Ash'ari 1977: 129). 
Kesemua kesepakatan manhaj menjelaskan kepada kita bahawa manhaj yang dibawa oleh al-Ash'ari merupakan manhaj yang jelas dipelopori dari manhaj ulama Salaf. Ketepatan di antara kedua manhaj ini membuahkan kesimpulan bahawa al-Ash'ari hakikatnya merupakan hasilan dari aliran Salaf, beliau hanya dibatasi dengan tempoh masa menyebabkan beliau tidak tergolong dari kalangan ulama Salaf sekalipun beliau hidup di zaman mereka dan berguru dengan mereka. Tetapi manhaj dan aliran beliau masih jelas merupakan kesinambungan dari manhaj Salaf yang mulia yang diteruskan oleh al-Ash'ari yang akhirnya membawa manhaj ini sehingga zaman sesudah beliau. Pada bab yang seterusnya pula akan dikembangkan isu kesinambungan pemikiran al-Ash'ari terhadap fahaman akidah Salaf dari sudut isu-isu utama yang timbul ketika zaman Salaf dan alAsh'ari yang akan memperlihatkan kesinambungan fahaman mereka dalam masalah akidah pula.

\section{Kesinambungan Pemikiran al-Ash'ari terhadap Fahaman Salaf dalam Persoalan Sifat}

Mengenai persoalan kesinambungan ulama salaf dalam pemikiran al-Ash'ari dalam masalah sifat, perkara yang perlu dibahaskan adalah dalam masalah pengisbatan sifat, sifat-sifat yang diisbatkan oleh mereka, pembahagian sifat zat dan sifat fi'il, masalah perbezaan antara sifat dan zat, dan masalah sifat khabariyyah.

Masalah Mengisbatkan Sifat bagi Allah

Dalam masalah sifat Allah kesemua ulama salaf dan Abu Hasan al-Ash'ari bersepakat bahawa bagi Allah mempunyai sifat dan sifat-sifat Allah tersebut adalah sesuatu yang disandarkan kepada Allah s.w.t dan bukan kepada sesuatu yang lain sebagaimana yang didakwa oleh golongan Muktazilah. Muktazilah meletakkan bahawa kalam Allah iaitu sifat Allah berada di dalam perut Maryam iaitu ibu Nabi Musa ketika mengandungkan Musa a.s dan juga kalam Allah terletak di pokok ketika mana Musa a.s berkata-kata dengan Allah. Begitu juga Muktazilah meletakkan Kalam Allah seperti alQuran itu sebagai baharu dengan tujuan asalnya menafikan sifat berada pada Zat Allah s.w.t.

Menurut Abu Hanifah, sifat Allah itu adalah azali dan Allah s.w.t bersifat dengan sifat-Nya yang azali. Mustahil bagi Allah itu bersifat dengan sifat yang baharu dan mustahil Allah juga bersifat dengan sifat yang bukan dari sifat-Nya yang azali. Allah berkata-kata dengan kalam-Nya sendiri dan Kalam-Nya itu adalah azali. Begitu juga dengan sifat qudrah, iradah dan lain-lain sifat (Abu Hanifah 1955: 23-24).

Imam Malik juga mengisbatkan bagi Allah mempunyai sifat sebagaimana salah satu dari riwayat Abdullah bin Nafi' yang berpendapat bahawa beliau mengucapkan Allah mempunyai ilmu dan ilmunya itu luas di setiap segenap penjuru tempat mengucapkan (al-Safarayni n.d: 199-200). Beliau tidak banyak membicarakan mengenai isu akidah dan malah menentang orang-orang yang sering membicarakan mengenai akidah dengan lebih mendalam melainkan didatangkan beserta dengan amal.

Imam Ahmad juga dengan jelas mengisbatkan sifat Allah tanpa menafikannya sebagaimana yang didakwa golongan Jahmiyyah yang menafikan bagi Allah ada sifat. Beliau menafikan bahawa Allah itu majhul iaitu sesuatu yang tidak diketahui ianya dengan sesuatu (iaitu sifat) (Ahmad bin Hanbal 1971: 68). Bagi Imam Ahmad, sifat adalah sesuatu yang dengan-Nya dapat dikenali Allah. Mustahil menurut beliau Allah sebagai pentadbir alam tidak dapat dikenali dengan sifat sebagai 'sesuatu' yang seharusnya dikenali ianya dengan sifat (Ahmad bin Hanbal 1971: 68). Kalimah yang dimaksudkan di atas adalah Allah s.w.t dan ianya adalah gambaran dalam mengisbatkan Allah sebagaimana yang disebut oleh Abu Hasan al-Khiyyat (al-Ash'ari 1969: 202). 
Imam al-Shafi'i juga sebagaimana imam-imam yang lain yang mengisbatkan bagi Allah mempunyai sifat yang Dia sendiri bersifat dengan-Nya. Bagi Imam al-Shafi'i, Allah mempunyai kalam (dan juga sifat-sifat Allah yang lainnya), dan kalam Allah itu bukanlah sesuatu yang lain dari Allah atau sesuatu yang berada di tempat yang selain dari Allah. Allah mempunyai sifat yang seharusnya layak baginya dan sifat tersebut dimiliki oleh Allah serta Allah bersifat dengan sifat-Nya iaitu kalam (al-Bayhaqi 1970: 408).

Menurut Ibn Kullab juga, Allah sejak azali mempunyai sifat yang mana dia bersifat dengan sifat-Nya dan sifat tersebut tidak lain adalah bukan terkeluar dari Zat-Nya atau selain dari Zat-Nya sebagaimana yang didakwa Muktazilah (al-Ash'ari 1950: 202). Ibn Kullab juga menolak pandangan golongan Mu'tazilah dan Jahmiyyah yang mendakwa tiada sifat bagi Allah kerana ditakuti berlakunya ta'addud al-qudama' dengan berpendapat bahawa pengisbatan sifat bagi Allah dan penafian sifat Allah berada di sesuatu tempat yang lain dari Zat-Nya yang dipegang oleh kesemua ulama Salaf ini adalah bertepatan dengan pandangan Abu Hasan al-Ash'ari yang juga mengisbatkan bagi Allah mempunyai sifat sebagaimana yang disifatkan-Nya di dalam al-Quran dan Sunnah.

Jikalau diteliti hakikatnya kesemua pandangan ulama salaf ini diambil oleh al-Ash'ari. AlAsh'ari juga mengisbatkan bagi Allah sifat, dan sifat sifat tersebut adalah sesuatu yang semestinya adalah hak Allah dan bukannya berada di suatu tempat yang lain bahawa (Ibn Taymiyyah 1321H: 235). Al-Ash'ari berpendapat bahawa Allah itu mempunyai sifat berkuasa dan hidup berdasarkan dari firman Allah (al-Quran 41:15; al-Quran 51:58):

Maksudnya: Tidakkah mereka memerhatikan Bahawa Allah Yang menciptakan mereka (dari tiada kepada ada) adalah lebih besar kekuatanNya dari mereka?

Maksudnya: Sesungguhnya Allah Dia lah sahaja Yang memberi rezeki (kepada sekalian makhlukNya, dan Dia lah sahaja) Yang mempunyai kekuasaan Yang tidak terhingga, lagi Yang Maha kuat kukuh kekuasaanNya.

Dan juga sifat taklim yang semestinya Allah yang berkata-kata dengan kalam-Nya dan bukan sesuatu yang lain dari Zat-Nya (al-Qur'an 4:164):

Maksudnya: Dan Allah telah berkata-kata kepada Nabi Musa Dengan kata-kata (secara langsung, tidak ada perantaraan).

Maksud taklim menurut al-Ash'ari adalah mushafahah bi al-Kalam, iaitu tidak harus sesuatu kalam si mutakallim berlaku kepada selain darinya yang sedang berkata-kata itu (al-Ash'ari 1977: 72). Beliau juga berdalilkan qiyas kepada mereka yang hendak menafikan sifat kalam bagi Allah s.w.t dengan bukti yang telah ditunjukkan, hujah yang pertama iaitu kesepakatan antara al-Ash'ari dan ulama Salaf mengenai pengisbatan sifat terhadap Allah telah sabit disepakati di antara keduadua aliran ini. Kesepakatan ini adalah kesepakatan yang berdiri di atas asas dalil dan hujah dari nas al-Quran dan Sunnah serta akal (al-Ash'ari 1962: 15). Seterusnya akan dibincangkan pula sifat yang telah diisbatkan oleh ulama Salaf dan al-Ash'ari.

\section{Isu Sifat-Sifat yang Diisbatkan}

Pandangan ulama Salaf kebanyakan dari kalangan mereka mengisbatkan sifat yang telah Allah s.w.t sifatkan pada diri-Nya dalam al-Quran dan Hadith. Mereka hanya mengisbatkan sifat kepada Allah apa yang diisbatkan-Nya dalam kedua-dua sumber Nas tersebut. Mereka tidak mengisbatkan sifat 
bagi Allah melalui jalan akal atau jalan yang lain selain dari apa yang hanya didatangkan oleh Allah dalam Nas al-Quran dan Sunnah. Bagi Imam Abu Hanifah, beliau telah mengisbatkan bagi Allah beberapa sifat sebagaimana yang terdapat dalam kitabnya Wasiyyah dan Fiqh al-Akbar serta kitab yang lain. Secara jelasnya Abu Hanifah telah mengisbatkan pada Allah beberapa sifat antaranya adalah sifat al-hayah, al-qudrah, al-'ilm, al-kalam, al-sam', al-Basr, al-iradah, al-takhliq, al-tarziq, alinsha', al-San' dan lain-lain dan kesemua sifat ini adalah qadim dan azali bagi Allah s.w.t. Sifat-sifat yang telah diisbatkan oleh Imam Abu Hanifah terhadap Allah adalah bersumberkan dari Nas alQuran dan Sunnah dan sifat ini sama sekali berbeza dengan sifat makhluk yang baharu dan dicipta. Menurut Abu Hanifah, mereka yang berpendapat bahawa sifat Allah adalah makhluk atau baharu atau tawaqquf atau ragu-ragu adalah kafir (Abu Hanifah 1955: 42). Abu Hanifah juga berpendapat bahawa sifat Allah adalah sifat yang berbeza dengan makhluk berdasarkan dari ungkapannya iaitu (Abu Hanifah 1955: 31-32):

"Sifat-sifat Allah sejak azali kesemuanya berbeza dan berlainan dengan sifat yang ada pada makhluk, Allah mengetahui tidak seperti ilmu kita, Allah berkuasa tidak seperti berkuasanya kita, Allah melihat tidak seperti melihatnya kita"

Dengan itu jelas dalam masalah sifat Zat Abu Hanifah telah mengisbatkan tujuh sifat iaitu sifat al-hayyah, al-qudrah, al-'ilm, al-kalam, al-sam', al-Basr, al-iradah dan kesemua sifat ini berbeza dengan sifat pada makhluk.

Manakala Sifat yang telah diisbatkan oleh Imam Malik dalam penulisannya tidak banyak diketahui melainkan hanya ungkapan beliau mengenai sifat khabariyyah sahaja yang menolak golongan Musyabbihah dan Mujassimah yang menyamakan Allah dengan makhluk. Manakala pegangan beliau terhadap sifat lain tidak ditemui kecuali hanya beberapa sifat fi'liyyah yang telah disebutkan dalam al-Quran. Imam Malik yang merupakan seorang ahli hadith juga tidak langsung menyukai pembicaraan dalam masalah ilmu kalam, malah melarang perbahasan yang membicarakan mengenai ilmu kalam. Beliau juga seorang yang menentang perbahasan mengenai sifat Allah dan menegah sesiapa meriwayatkan hadith sifat (al-Nashshar 1977: 243). Walaubagaimanapun pegangan kita terhadap pandangan beliau mengenai sifat adalah seperti mana yang kita ketahui bahawa golongan salaf hanyalah mengisbatkan apa yang diisbatkan Allah s.w.t tanpa melakukan penambahan atau pengurangan.

Imam Ahmad pula telah mengisbatkan bagi Allah beberapa sifat antaranya adalah sifat qudrah, iradah, 'ilm, kalam, sama', basar, 'usmah, nur, al-awwal, al-akhir, dan beberapa sifat yang lainnya. Ini berdasarkan dari penulisannya yang menolak pandangan golongan Jahmiyyah yang menafikan bagi Allah ada sifat yang layak baginya (Ahmad bin Hanbal 1971:68, 87-88).

Kesemua sifat yang diisbatkan oleh Imam Ahmad juga sebagaimana ulama salaf yang lain yang mengisbatkan apa yang diisbatkan oleh Allah dalam al-Quran tanpa berlaku penambahan atau pengurangan. Hakikatnya ada beberapa lagi sifat yang diisbatkan beliau secara tidak langsung dalam penulisannya tetapi apa yang utamanya disini adalah metodologi pengisbatannya adalah berdasarkan kepada apa yang didatangkan dari Nas sahaja.

Sifat yang telah diisbatkan oleh Ibn Kullab pula ada beberapa sifat sebagaimana yang telah dinukilkan oleh al-Nashshar dalam kitabnya. Ibn Kullab yang merupakan seorang tokoh ulama salaf yang juga merupakan seorang mutakallimin abad ke-300 Hijrah juga telah mengisbatkan sifat sebagaimana yang diisbatkan oleh ulama salaf yang lainnya. Apa yang berbezanya beliau dari kalangan ulama salaf lain adalah beliau lebih memperincikan sedikit beberapa sifat dan melakukan pembahagian sifat tersebut kepada dua iaitu sifat zatiyyah dan fi'liyyah yang akan dibincangkan selepas ini. Antara sifat yang telah diisbatkan oleh Ibn Kullab sebagaimana yang dinukilkan oleh al- 
Ash'ari dalam penulisannya adalah 'Alim, Qadir, Hayy, Sami', BaSir, Mutakallim, 'Aziz, Jalil, Kabir, 'AZim, Jawwad dan lain-lain sifat fi'liyyah (al-Ash'ari 1950: 270, 202).

Kesemua sifat ini disifatkan oleh Allah sebagaimana yang Dia sifatkan dalam Nas dan Allah bersifat Qadir dengan Qudrah-Nya, 'Alim dengan 'ilmu-Nya, Sami' dengan Sama'-Nya dan lain-lain. Allah juga tidak memindahkan kalam-Nya kepada pokok atau tempat selain dari Zat-Nya kerana bagi Allah itu ada sifat dan sifat-Nya itu bukanlah lain dari Zat-Nya. Kesemua sifat-sifat yang telah diisbatkan oleh ulama salaf itu dapat dilihat ada beberapa sifat yang disepakati oleh ulama salaf terutamanya adalah berkaitan dengan sifat Ma'ani yang tujuh itu iaitu qudrah, iradah, 'ilm, kalam, sama', baSar dan sifat yang lain itu sebahagiannya ada yang disepakati dan sebahagian yang lain dimasukkan dalam sifat-Nya yang lain. Manakala dalam masalah sifat salbiyyah pula kebanyakan ulama salaf tidak membicarakannya dan hanya menukilkannya dalam bentuk penjelasan secara tidak langsung terhadap golongan yang sesat seperti yang dilakukan oleh Imam Ahmad. Beliau mengisbatkan sifat Qadim dan Baqa' dengan menggunakan istilah al-Awwal al-Akhir kerana ianya sabit dari sudut Nas al-Quran. Manakala mengenai sifat Khabariyyah pula akan dibincangkan selepas ini.

Manakala sifat-sifat Allah yang telah diisbatkan oleh al-Ash'ari secara umumnya ada tiga belas yang mana pengisbatan kepada sifat-sifat Allah ini dilakukan berdalilkan kepada Nas al-Quran dan Sunnah dan melalui jalan qiyas sebagaimana yang telah disebut oleh al-Ash'ari sebelum ini. Kesemua sifat yang diisbatkan beliau kesemuanya melalui metodologi Nas dan Qiyas bagi memperkuatkan hujah dan dalil kepada pengisbatan sifat-sifat ini. Al-Ash'ari secara ringkasnya telah mengisbatkan sifat wujud, qidam, baqa', mukhalafatuh li al-hawadith, qiyamuhu bi nafsihi, wahdaniyyah, qudrah, iradah, 'ilm, hayy, sama', basar, kalam.

Al-Ash'ari telah mengisbatkan sifat 'ilm dan qudrah (al-Ash'ari 1994:107). Kedua-dua sifat ini menurut al-Ash'ari telah dinaskan oleh al-Quran dalam banyak ayat antaranya bagi sifat 'ilm (alQuran 4:166):

Maksudnya: Allah menurunkannya dengan ilmu-Nya.

Bagi sifat qudrah dan hayy juga al-Ash'ari telah berdalilkan dari beberapa ayat al-Qur'an antaranya (al-Quran 41:15):

Maksudnya: Tidakkah mereka memerhatikan Bahawa Allah yang menciptakan mereka (dari tiada kepada ada) adalah lebih besar kekuatan-Nya dari mereka?

Al-Ash'ari juga mengisbatkan bagi Allah sifat sam' dan baSar berdasarkan dari firman Allah s.w.t (al-Quran 31: 28):

Maksudnya: Sesungguhnya Allah Maha Mendengar, lagi Maha Melihat.

Dari ayat ini beliau telah mengisbatkan sifat sam' dan baSar berdasarkan dari Allah Maha Mendengar dan Melihat. Beliau menafikan pandangan dari golongan Muktazilah yang meletakkan bahawa sam' dan baSar Allah itu bermaksud 'Alim dari sifatnya yang mana sifat 'Alim itu pula adalah Zat Allah itu sendiri (al-Ash'ari 1977: 157-158).

Beliau juga mengisbatkan sifat kalam dan sifat iradah bagi Allah s.w.t berdasarkan dari dalil (al-Quran 4:164): 
Maksudnya: Dan Allah telah berkata-kata kepada Nabi Musa Dengan kata-kata (secara langsung, tidak ada perantaraan).

Maksud taklim menurut al-Ash'ari adalah mushafahah bi al-Kalam, iaitu tidak harus sesuatu kalam si mutakallim berlaku kepada selain darinya yang sedang berkata-kata itu (al-Ash'ari 1977: 72). Beliau juga berdalilkan qiyas kepada mereka yang hendak menafikan sifat kalam bagi Allah s.w.t (al-Ash'ari 1962: 15). Al-Ash'ari juga mengisbatkan sifat Murid bagi Allah terhadap iradah-Nya dengan dalil qiyas iaitu apabila Ia berkehendak nescaya Ia berkehendak dengan iradah-Nya (alAsh'ari 1962: 15). Dalam mengisbatkan wujud pula, al-Ash'ari tidak mengkategorikannya sebagai salah satu daripada sifat tetapi hanya bukti kewujudan dan ia boleh berlaku melalui beberapa cara iaitu melalui khabar dan juga akal (al-Ash'ari 1962: 6). Al-Ash'ari membuktikan wujud Allah itu berubahnya alam ini dan dalil dari al-Quran yang menunjukkan Allah sebagai pencipta kepada makhluk (al-Quran 56:58-59):

Maksudnya: (Mengapa kamu masih berdegil?) tidakkah kamu memikirkan keadaan air mani Yang kamu pancarkan (ke Dalam rahim)? Adakah kamu Yang menciptakannya atau Kami Yang menciptakannya?

Al-Ash'ari juga membawa dalil qiyas mengenai wujudnya Allah berdasarkan berubahnya alam ini (al-Ash'ari 1962: 6):

"Sekiranya seorang bertanya: Apakah bukti yang menunjukkan setiap ciptaan ada pencipta yang mencipta dan pentadbir yang menguruskannya? Jawabnya: Buktinya bahawa manusia yang paling sempurna kejadiannya adalah berasal daripada air mani, lalu menjadi segumpal darah beku, seketul daging dan seterusnya daging, tulang dan darah. Seperti yang kita ketahui bahawa proses kejadian ini tidak berubah daripada satu keadaan kepada keadaan yang lain dengan kehendak manusia... Berdasarkan apa yang kita nyatakan ini membuktikan bahawa bukanlah manusia yang mengubah keadaan dirinya dalam semua keadaan tersebut, bahkan terdapat pengubah yang mengubah daripada satu keadaan kepada keadaan yang lain dan yang menguruskan setiap perubahan tersebut. Ini kerana perubahan daripada satu keadaan kepada keadaan yang lain tanpa ada pengubah atau pentadbir adalah suatu yang mustahil".

Al-Ash'ari juga mengisbatkan bahawa Allah tidak menyerupai makhluk iaitu bersalahan Allah dengan segala yang baharu iaitu mengisbatkan sifat mukhalafatuh li al-hawadith berdasar pada firman Allah (al-Qur'an 42:11):

Maksudnya: Tiada sesuatupun yang sebanding dengan (ZatNya, sifat-sifatNya, dan pentadbiranNya) dan Dia lah Yang Maha Mendengar, lagi Maha Melihat.

Beliau juga membawakan dalil dari qiyas bahawa Allah tidak langsung menyerupai makhluk dari segenap segi (al-Ash'ari 1962: 8):

"Sekiranya seseorang bertanya: Kenapa kamu beranggapan bahawa Allah SWT tidak seperti makhluk? Jawabnya: Sekiranya Allah SWT sama seperti makhluk maka hukum-Nya sama dengan makhluk dari aspek baharu. Jika Allah SWT sama seperti 
makhluk, sama ada serupa dari semua sudut ataupun sebahagian sahaja. Sekiranya sama dari semua sudut maka Allah SWT juga adalah baharu seperti makhluk. Sekiranya sama dari sebahagian sudut sahaja, maka Allah SWT baharu dari aspek tersebut. Adalah mustahil bagi sesuatu yang baharu pada masa yang sama bersifat qadim".

Al-Ash'ari juga mengisbatkan sifat wahdaniyyah pada hakikat Zat Allah s.w.t dengan berdalilkan dari al-Quran (21:22):

Maksudnya: Kalau ada di langit dan di bumi tuhan-tuhan yang lain dari Allah, nescaya rosaklah pentadbiran kedua-duanya. maka (bertauhidlah kamu kepada Allah Dengan menegaskan): Maha suci Allah, Tuhan yang mempunyai Arasy, dari apa yang mereka sifatkan.

Beliau juga berdalilkan dari nas qiyas yang menunjukkan Allah mustahil ada sekutu iaitu qiyamuhu bi nafsihi dan wahdaniyyah. Beliau menyebut (al-Ash'ari 1962: 8):

"Sekiranya seseorang bertanya: Kenapakah engkau mendakwa bahawa pencipta segala sesuatu itu Esa? Jawabnya: Dua pentadbir tidak dapat mentadbir satu perkara dengan teratur dan berkesan. Pasti akan berlaku kelemahan pada keduaduanya ataupun salah satu daripadanya. Ini kerana, apabila salah satu daripadanya ingin menghidupkan seorang insan sedangkan yang satu lagi ingin mematikannya. Hal ini menyebabkan berlaku salah satu daripada tiga keadaan berikut, iaitu kehendak kedua-duanya terlaksana, atau kehendak kedua-duanya tidak terlaksana, atau hanya kehendak salah satu sahaja yang terlaksana. Justeru mustahil akan terlaksana kehendak kedua-duanya kerana satu jasad tidak boleh hidup dan mati pada masa yang sama. Sekiranya tidak terlaksana kehendak kedua-duanya, maka pastilah kedua-duanya itu lemah, yang lemah tidak boleh menjadi tuhan dan tidak qadim".

Dari kesemua 13 sifat yang telah diisbatkan oleh al-Ash'ari, kesemuanya berasaskan kepada dalil Nas al-Quran tanpa suatupun yang terkeluar dari dilalah yang dibuktikan dari pengambilan melalui Nas sama ada al-Quran mahupun sunnah (al-Ash'ari 1977: 20-21). Kesepakatan al-Ash'ari dengan fahaman ulama salaf dalam masalah sifat Allah yang diisbatkan telah jelas diperlihatkan dari pandangan-pandangan ulama salaf dan al-Ash'ari di atas. al-Ash'ari jelas bertepatan pengisbatan sifatnya dengan pandangan dari Abu Hanifah dan Ibn Kullab dari keseluruhan sifat ma'ani dan sebahagian dari Ahmad bin Hanbal dan Imam Malik. Ini adalah kerana keterbatasan perbincangan dua orang ulama Ahli Hadith ini iaitu Imam Ahmad dan Imam Malik dalam permasalahan sifat dan malah Imam Malik sendiri menegah mereka yang berbincang mengenai isu sifat terutamanya orang yang meriwayatkan hadith sifat sebagaimana yang telah dijelaskan sebelum ini. Dalam perbincangan mengenai sifat salbiah juga hakikatnya al-Ash'ari menyamai dengan pengisbatan yang dilakukan oleh Imam Ahmad dari beberapa sifat antaranya adalah qidam, baqa', wahdaniyyah dan lain-lain. Walaupun kebanyakan dari kalangan ulama' salaf tidak menyebut secara jelas satu persatu sifat Allah dan juga tidak membahagikan sifat Allah, tetapi konsep umum mereka telah pun kita ketahui sebagaimana yang pernah dijelaskan sebelum ini iaitu mereka mengisbatkan sifat sebagaimana yang telah Allah isbatkan di dalam al-Quran. Mereka tidak menambah atau mengurangi walau suatu pun dari sifat Allah yang telah diisbatkan oleh Allah 
melalui al-Qur'an dan khabar dari Nabi-Nya (al-Shahrathani 1968: 2). Kesemua sifat yang diisbatkan oleh mereka, dalam konteks pembahagian sifat, merangkumi sifat nafsiyah, salbiyah, ma'ani, sifat Zat, sifat fi'il, dan juga sifat Khabariyyah.

Menurut al-Shahrathani (1968: 92), sikap golongan Salaf adalah mengisbatkan sifat azali bagi Allah seperti sifat 'Ilm, Qudrah, Hayah, Iradah, Sama', Basar, Kalam, al-Jalal, al-Kiram, al-Jud, alIn'am, al-'Izzah dan al-'Azamah. Mereka tidak membezakan antara sifat-sifat tersebut sebagai sifat zat atau sifat fi'il dan hanya menganggap kesemua sifat tersebut adalah satu. Mereka mengisbatkan bagi Allah sifat-sifat tersebut kerana sifat-sifat tersebut terkandung dalam nama-nama Allah seperti 'ilm di ambil dari nama Allah iaitu 'Alim dan juga sifat-sifat yang lain. Mereka juga mengisbatkannya kerana sifat tersebut telah dikhabarkan oleh oleh Allah dan juga Rasul-Nya sekalipun ia tidak terdapat dalam nama-Nya seperti sifat kasih sayang pada hamba-Nya yang mukmin dan bertaqwa. Sebagaimana yang diriwayatkan dari Imam al-Shafi'i bahawa "Aku beriman dengan apa yang aku dapati dari Allah dan dari Rasulullah" (Ibn Taymiyyah 1999: 21). Hujah dan dalil mereka dalam mengisbatkan sifat bagi Allah adalah berasaskan kerana ianya terdapat dalam al-Qur'an dalam bentuk ayat muhkam, sama ada nama-nama-Nya, sifat zat atau sifat fi'il dan juga terdapat dalam hadith (al-Hukmi n.d.: 310-318).

\section{Pembahagian Sifat Zat dan Sifat Fiil}

Dalam masalah pembahagian sifat zat dan sifat fi'il, pemikiran al-Ash'ari lebih mendekati kepada fahaman akidah Abu Hanifah, dan Ibn Kullab yang membahagikan sifat ini dan secara fokusnya menyebut dalam penulisannya tentang pembahagian mereka. Abu Hanifah dan Ibn Kullab membahagikan sifat Allah itu kepada dua iaitu Sifat Zat dan Sifat Fi'l dan kedua-dua sifat ini menurut Abu Hanifah adalah qadim manakala menurut pandangan Ibn Kullab ianya adalah baharu. Menurut Abu Hanifah setiap sifat yang disandarkan pada Allah adalah qadim dan mustahil bagi Allah memerlukan sifat yang baharu bagi-Nya. Allah hanyalah bersifat dengan apa yang selayak bagi-Nya. Manakala bagi Ibn Kullab sifat Fi'l adalah sifat yang baharu dan berbeza dengan sifat Zat, tetapi dalam aliran Kullabiyyah juga tidak diberi penjelasan yang mendalam mengenai sifat Zat dan Sifat Fi'l. Apa yang dapat dilihat adalah pembahagian yang dilakukan oleh al-Ash'ari sebagai salah seorang murid kepada Ibn Kullab dengan perbahasan yang jelas di antara sifat Zat dan sifat Fi'l. alGhurabiyy menyebut bahawa Abu Hanifah membahagikan sifat Allah kepada dua bahagian iaitu sifat Zatiyyah dan sifat Fi'liyyah. Sifat Zatiyyah dari pandangan Abu Hanifah adalah sifat yang Allah tidak boleh bersifat dengan sifat lawannya dan tidak berkuasa untuk bersifat dengan sifat lawannya seperti sifat mengetahui. Allah tidak boleh bersifat dengan sifat jahil dan tidak ada kuasa untuk bersifat dengan sifat jahil. Manakala Sifat Fi'liyyah adalah sifat yang Allah boleh bersifat dengannya dan juga lawannya sebagai contohnya $a l-H u b b$. Allah juga boleh bersifat dengan lawan bagi sifat itu iaitu al-Bughd (al-Ghurabi n.d: 226).

Sifat Zatiyyah yang wujud pada Allah menurut Imam Abu Hanifah adalah al-hayyah, alqudrah, al-'ilm, al-kalam, al-sam', al-Basr, al-iradah. Manakala sifat Fi'liyyah pula adalah al-takhliq, al-tarziq, al-insha', al-San' dan lain-lain. Kesemua sifat-sifat ini adalah qadim (Abu Hanifah 1955: 42). Menurut Abu Hanifah lagi, mereka yang berpendapat bahawa sifat Allah adalah makhluk atau baharu atau tawaqquf atau ragu-ragu adalah kafir (Abu Hanifah 1955: 42).

Manakala sifat zatiyyah menurut Ibn Kullab pula adalah 'Alim, Qadir, Hayy, Sami', BaSir, 'Aziz, Jalil, Kabir, 'Azim, Jalil, Kabir, Karim, Jawwad, Mutakabbir, Wahid, Ahad, Samad, Fard, Baqi, Awwal, Sayyid, Malik, Rabb, Rahman, Murid dan lain-lain (al-Ash'ari 1950: 202). Manakala dalam masalah sifat Kalam menurut Ibn Kullab pula, beliau memecahkannya kepada sifat zat yang qadim sama seperti sifat yang lain di atas dan sifat fi'l yang baharu yang hanya berlaku ketika hadirnya 
mukhatab. Menurut Ibn Kullab, kalam Allah dibahagikan kepada dua iaitu sifat Zat-Nya iaitu KalamNya yang sebenar yang qadim dan azali, dan juga sifat Fi'l-Nya iaitu Kalam yang berupa amr, nahy, dan khabar yang tidak qadim. Beliau mengisbatkan sifat Kalam sebagai sifat Zat sebahagiannya dan Sifat Fi'l sebahagian yang lain (al-Subki 1964: 52).

Dalam masalah sifat fi'liyyah beliau mengisbatkan bagi Allah ada sifat Fi'l yang tidak qadim atau baharu, iaitu kalam Allah yang berbentuk amr, nahy, dan khabar. Sifat Fi'l ini tidak qadim dan tidak wujud melainkan hadirnya mukhatab iaitu orang kedua yang dikatakan satu kalam padanya. Menurut al-Subki (1964: 52), Ibn Kullab dan Abu al-Abbas al-Qalansi membahagikan kalam Allah kepada dua, dan Allah tidak bersifat dengan amr, nahy, dan khabar sejak azali kerana baharunya suruhan, tegahan dan khabar yang disampaikan, dan kerana qadimnya kalam nafsi iaitu sifat bagi dirinya dan Allah bersifat dengan sifat kalam nafsi itu sejak azali. Al-Nashshar (1977: 267) menjelaskan, maksud Ibn Kullab dan al-Qalansi mengenai kalam Allah adalah, Ibn Kullab hakikatnya membahagikan kalam Allah kepada dua iaitu yang pertamanya kalam Allah yang nafsi yang qadim sejak mula lagi, dan yang kedua adalah kalam amr, nahy, dan khabar iaitu kalam yang baharu dan kalam amr, nahy, dan khabar ini berta'alluq dengan perkara yang baharu kerana itu kalam Allah yang khas ini iaitu $a m r$, nahy, dan khabar adalah kalam yang baharu.

Oleh kerana itu pemahaman mengenai sifat Fi'l menurut Ibn Kullab ini dapat difahami dengan membezakan kalam Allah yang nafsi iaitu yang qadim yang sememangnya berada dengan Allah sejak azali dan kalam yang bersifat perlu kepada mukhatab iaitu sesuatu yang baharu, yang datangnya apabila wujudnya mukhatab. Ketika itu baharulah wujudnya kalam yang berbentuk amr, nahy dan khabar dari kalam Allah.

Pembahagian sifat ini hakikatnya tidak dinyatakan atau dibincangkan secara jelas oleh alAsh'ari kerana al-Ash'ari lebih mendekati dengan pandangan Imam Ahmad bin Hanbal. Walaubagaimanapun terdapat juga sebahagian pendapat yang menyentuh mengenai pemikiran alAsh'ari yang menepati pendapat Ibn Kullab dalam masalah sifat Fi'l. Menurut al-Ash'ari sifat itu terbahagi kepada dua iaitu sifat Zatiyyah dan sifat Fi'liyyah. Sifat Zatiyyah diisbatkan oleh al-Ash'ari dengan 13 sifat sebagaimana yang telah dijelaskan sebelum ini antaranya qudrah, iradah, 'ilm, hayy, sam', baSar dan kalam. Sifat Fi'liyyah adalah sifat yang Allah bersifat dengannya seperti sifat alTakwin, Rahman, Rizq, dan lain-lain selain dari sifat Zatiyyah tersebut. Sifat-sifat ini boleh Allah bersifat dengannya atau lawannya. Al-Ash'ari berpendapat bahawa kesemua sifat-sifat ini adalah sifat yang nisbi atau hadith iaitu sifat yang baharu. Berbanding dengan pandangan dari al-Maturidi yang meletakkan bahawa sifat fi'liyyah merupakan sifat yang qadim bersama dengan Zat Allah (Fath Allah Khalif 1970: 36-37).

Pemikiran al-Ash'ari mengenai pembahagian sifat Zat dan Sifat Fi'l akhirnya dikembangkan oleh muridnya yang merupakan tokoh Asha'irah yang terawal iaitu Abu Bakr al-Baqillani. Ketika zaman al-Baqillani beliau mengembangkan pandangan al-Ash'ari dengan lebih terperinci iaitu dengan membahagikan sifat zat dan sifat fi'il dan meletakkan sifat-sifat yang Allah bersifat dengan sifat zat dan sifat yang Allah bersifat dengan sifat Fi'l. Menurut al-Baqillani sifat Zat sifat azali yang Allah bersifat dengannya sejak azali. Manakala sifat fi'l adalah sifat yang baharu yang Allah mendahului sifat itu. Sekalipun sifat fi'l adalah sifat yang baharu, tetapi gambaran (iaitu) bagi sifat tersebut adalah tetap qadim seperti sifat kalam yang dibicarakan oleh Ibn Kullab (al-Baqillani 1967: 262-263). Kerana itu bagi al-Baqillani dan al-Ash'ari selaku gurunya, pandangan mereka lebih menepati kepada pandangan ulama salaf Ibn Kullab dalam masalah sifat Zat dan sifat Fi'l secara terperinci dan menepati juga pandangan Abu Hanifah dalam masalah pembahagian sifat. Walaubagaimanapun pandangan al-Ash'ari berbeza dengan Abu Hanifah dari sudut ma'na dalam perbahasan terhadap sifat fi'liyyah kerana bagi Abu Hanifah, kesemua sifat termasuk sifat fi'liyyah adalah qadim berbanding al-Ash'ari dan Ibn Kullab yang meletakkan sifat fi'liyyah sebagai baharu.

https://doi.org/10.24035/ijit.16.2019.007 


\section{Masalah Sifat Khabariyyah}

Dalam masalah sifat khabariyyah, pandangan ulama salaf mengenainya berbeza-beza. Walaubagaimanapun kesemua mereka bersepakat mengisbatkan sifat khabariyyah bagi Allah sebagaimana yang Allah khabarkan melalui al-Quran dan Sunnah. Perbezaan dari kalangan mereka hanyalah dari sudut perbincangan mengenainya. Sebahagian dari kalangan mereka memperincikan maksud yang dikehendaki dari masalah sifat khabariyyah dan sebahagian lagi hanya menyerahkan makna sebulat-bulatnya pada Allah s.w.t dan mereka tidak memperdalami maknanya.

Imam Abu Hanifah dalam masalah sifat Khabariyyah berpegang teguh dengan ayat yang telah diturunkan oleh Allah sebagaimana yang digambarkan-Nya. Cara penghujahan Abu Hanifah adalah mengisbatkan bagi Allah kesemua sifat Khabariyyah yang telah dikhabarkannya dan dalam masa yang sama beliau menafikan bahawa Allah itu bersifat dengan zahir ayat tersebut. Abu Hanifah juga menolak pentakwilan rosak yang dilakukan oleh golongan Muktazilah dan Qadariyyah yang mentakwilkan sifat khabariyyah tersebu (Abu Hanifah 1955: 36-37). Imam Abu Hanifah juga menafikan bagi Allah ada tempat dan arah sebagaimana yang dilakukan oleh golongan mujassimah dan menafikan bahawa Allah itu berhajat kepada sesuatu yang telah dicipta-Nya (Abu Hanifah 2009: 142).

Imam Malik yang merupakan seorang ulama hadith di zamannya tidak banyak membicarakan masalah sifat Allah, malah menentang mereka yang meriwayatkan hadith mengenai sifat sebagaimana yang telah dijelaskan sebelum ini. Walaubagaimanapun dalam masalah sifat khabariyyah, beliau seolahnya telah mengambil jalan cut-off atau meletakkan pendirian yang tegas mengenai ayat mutashabihat atau sifat khabariyyah tanpa memberi laluan untuk berjidal mengenainya. Imam Malik berpendapat (al-Nashshar 1977: 243):

"al-Istiwa' perkara yang dimaklumi, hal keadaannya tidak diketahui, beriman dengannya adalah wajib, bertanya mengenainya adalah perkara bidaah".

Ungkapan الاستواء معلومٌ seolahnya telah menggambarkan bahawa semua orang telah mengetahui mengenai ayat istiwa' yang telah diturunkan oleh Allah dan secara zahirnya semua و الكيف مجهو Jُyang telah membayangkan bahawa beliau menafikan segala bentuk percanggahan pendapat dari golongan mushabbihah dan mujassimah yang meletakkan makna istawa dengan perkara yang boleh dilihat, dirasa, disentuh dan juga menolak pandangan aliran Mu'tazilah yang mentakwil ayat istawadengan takwilan yang rosak. Kalimah والسؤال عنه بدعةٌ pula membayangkan pada kita sikap seorang ulama salaf yang tidak mahu perbicaraan lanjut mengenai ayat ini diteruskan bagi mengelakkan berlakunya penyelewengan dan pentakwilan yang merosakkan dan terkeluar dari makna yang dikehendaki oleh Allah. Ia juga membayangkan bahawa Imam Malik telah menyerahkan makna sebulatnya pada Allah tanpa menafsirkan kalimah istawa tersebut dengan duduk seperti golongan mujassimah atau berkuasa seperti golongan Muktazilah (al-Safarayni n.d.: 199-200).

Imam Ahmad juga mengambil jalan tafwid sebagaimana yang dilakukan oleh ulama salaf sebelum beliau. Bahkan beliau sebagaimana Imam Abu Hanifah menafikan bahawa Allah mengambil tempat. Beliau juga menolak pandangan golongan Jahmiyyah bahawa Allah itu berada di bumi di bawah tujuh lapisannya. Beliau juga menolak penafian golongan Jahmiyyah bahawa Allah istawa di atas 'arash (Ahmad bin Hanbal 1971: 92). Imam Ahmad mengisbatkan Sifat Khabariyyah sebagaimana yang disifatkan oleh Allah tanpa takwil, tanpa kayf, dan hanya 
mengisbatkan sifat khabariyyah sebagaimana yang Allah sifatkan dalam al-Quran tanpa takwil dan ta'til. Beliau juga mengisbatkan bahawa Allah fI al-Sama' tanpa meletakkan tempat pada Allah (Ahmad bin Hanbal 1971: 93). Beliau juga pernah menafsirkan dari ayat mutashabihat وهو الله dengan maksud bahawa Allah itu adalah tuhan kepada setiap yang berada di langit dan bumi dalam al-Radd 'Ala al-Zanadiqah Wa al-Jahmiyyah (Ahmad bin Hanbal 1971: 93-94).

Imam al-Shafi'i pula dalam masalah sifat khabariyyah mengambil jalan yang sama dengan Imam Malik dan golongan salaf yang lainnya. Ungkapan beliau menggambarkan sikap yang berlepas diri dari mendalami masalah mutashabihat sebagaimana yang dilakukan oleh Imam Malik (al-Safarayni n.d: 200). Walaubagaimanapun Muhammad Salum (1966: 139) telah merumuskan pandangan Imam al-Shafi'i dalam masalah sifat khabariyyah. Menurut Imam al-Shafi'i, Allah beristawa sebagaimana yang terdapat dalam al-Quran dan Hadith, dan kaifiyat istawa Allah itu adalah mengikut yang layak pada Zat-Nya yang mulia dan tidak seperti istawa manusia. Istawa Allah s.w.t tidak langsung melibatkan jisim sebagaimana yang difahami oleh setengah orang kerana mereka memahami maksud istawa yang dikehendaki adalah seperti istawanya makhluk sedang istawa Allah adalah istawa yang layak bagi Zat-Nya. Imam al-Shafi'i juga secara jelas mengambil sikap salaf dengan menolak mutakallimin dari kalangan Muktazilah dan lain-lain fahaman ketika zaman beliau kerana kesesatan mereka. Sungguhpun begitu, hakikatnya beliau juga seorang ulama kalam yang mempelajari ilmu kalam seorang yang sangat faham mengenai selok-belok ilmu kalam, tetapi beliau menentang golongan mutakallimin yang sesat dan menyeleweng seperti golongan Qadariyyah dan Muktazilah sehingga mentakwil sifat khabariyyah dengan takwilan akal yang rosak (Abu Zuhrah 1948: 135).

Ibn Kullab juga mengambil jalan sebagaimana ulama salaf yang lain dalam masalah sifat khabariyyah. Beliau juga sebagaimana yang diriwayatkan al-Ash'ari mengisbatkannya tanpa takwil kalam yang rosak (al-Ash'ari 1969: 205). Menurut al-Nashshar (1977: 269) beliau juga menolak bagi Allah itu mempunyai tempat, jisim dan arah sebagaimana yang dilakukan oleh golongan mujassimah. Beliau menyebut bahawa Allah istiwa' 'ala al-'Arash akan tetapi kayfiyat bagi istiwa' itu tiada. Allah juga bukan sesuatu yang bermasa serta bertempat, kerana Allah sejak azali telahpun wujud sebelum penciptaan pada tempat dan masa.

Masalah Sifat Khabariyyah menurut pandangan al-Ash'ari juga tidak berbeza dengan apa yang telah diriwayatkan oleh golongan salaf. al-Ash'ari mengisbatkan sifat wajh dan yadd bagi Allah (al-Ash'ari 1977:122). Beliau tidak menentukan wajh dan yadd itu dengan bagaimana. Tetapi beliau hanya mengisbatkannya tanpa kayf dan tanpa ta'til. Bagi Allah ada wajh dan wajh itu tidak menerima kemusnahan, dan ada yadd serta menafikan pandangan yang mentakwilkan yadd dengan ni'mah (al-Ash'ari 1977: 126). Mereka yang mentakwilkan sifat khabariyyah ini menurut al-Ash'ari adalah golongan yang sesat dan pelaku bid'ah kerana tidak sabit melalui bahasa dan Nas atau ijma' (al-Ash'ari 1977: 128). Al-Ash'ari juga mengisbatkan bagi Allah sifat 'aynayn dengan tiada kayf dan had berdasarkan firman Allah s.w.t واصنع الفلك بأعينا dan بتري بأعينن (al-Ash'ari 1977: 120). Al-Ash'ari juga mengisbatkan bahawa Allah istiwa' 'ala al-'Arash dengan tiada kayf bagi istiwa'nya dan beliau mengisbatkan istiwa' ini dengan cara yang selayaknya bagi Allah s.w.t (al-Ash'ari 1977: 105). Imam al-Ash'ari juga menolak pengisbatan takwil kalami pada makna istiwa' sebagaimana yang dilakukan al-Mu'tazilah, Jahmiyyah, dan Haruriyyah yang mentakwilkan dengan takwilan kalami lafaz istiwa' dengan makna berkuasa dan memiliki (al-Ash'ari 1977: 108). Dapat dilihat bagaimana metodologi pengisbatan yang dilakukan oleh al-Ash'ari bertepatan dengan apa yang dilakukan oleh golongan salaf dalam masalah sifat khabariyyah. Kerana itu dapat dilihat kesinambungan fahaman beliau dalam masalah ini bertepatan dengan apa yang difahami oleh golongan salaf tanpa sedikit pun terkeluar dari kaedah dan metologi yang telah disepakati oleh ulama salaf yang lainnya. 
Berdasarkan kepada keseluruhan analisis terhadap isu sifat di antara golongan ulama Salaf dan al-Ash'ari, jelas bahawa al-Ash'ari telah menepati manhaj dan metode pengambilan yang digunakan ulama salaf terutamanya dalam isu sifat. Dalam masalah pembahagian sifat dan pengisbatan sifat, kesemua 13 sifat yang telah diisbatkan dan dibahagikan oleh al-Ash'ari berasaskan kepada dalil Nas al-Quran tanpa suatupun yang terkeluar dari dilalah yang dibuktikan dari pengambilan melalui Nas sama ada al-Qur'an mahupun sunnah. Malah al-Ash'ari sendiri membuat pengakuan mengenai metodologi pengisbatan beliau dalam masalah akidah (al-Ash'ari 1977: 20-21):

$$
\text { وقولنا الذي نقول به ، وديانتنا التي ندينا بها: التمسك بكتاب الله ربنا عز وجل ، وبسنتي نبينا محمد صلى الله عليه }
$$

Kesepakatan al-Ash'ari dengan fahaman ulama salaf dalam masalah sifat Allah yang diisbatkan telah jelas diperlihatkan dari pandangan-pandangan ulama salaf dan al-Ash'ari di atas. Manakala dalam persoalan pembahagian di antara sifat zat dan sifat fi'l juga al-Ash'ari telah mengambil jalan yang sama dengan para ulama salaf terutamanya sebagaimana yang diambil oleh Abu Hanifah dan Ibn Kullab. Kedua mereka membahagikan sifat Allah itu kepada dua iaitu Sifat Zat dan Sifat Fi'l dan kedua-dua sifat ini khilaf di antara para ulama Salaf. Mengenai dengan masalah sifat khabariyyah juga al-Ash'ari lebih mendekati manhaj majoriti ulama Salaf yang mengambil pendekatan tafwid terhadap sifat-sifat tersebut. Secara umumnya, jelas bahawa interaksi di antara al-Ash'ari dan para ulama Salaf terhadap persoalan sifat adalah suatu kesinambungan di antara satu sama lain. Dapat dilihat pendekatan beliau adalah menepati dengan apa yang dibawa oleh para ulama salaf.

\section{Penghargaan}

Penyelidikan ini adalah dibiayai sepenuhnya oleh Geran Galakan Penyelidik Muda. Penghargaan ditujukan kepada Geran Galakan Penyelidik Muda, Kod Geran GGPM-2018-031

\section{References}

al-Quran.

Abu Hanifah, Nu'man bin Thabit. 1955. Fiqh al-Akbar. In Mulla 'Ali Ibn Sultan Muhammad al-Qari. Sharh 'ala Fiqh al-Akbar. Cairo: Matba'ah Mustafa al-Babi al-Halabi.

Abu Zuhrah, Muhammad. 1948. Al-Shafi'i: Hayatuhu wa 'Asruhu, Ara'uhu wa Fiqhuhu. Cairo: Dar al-Fikr al-'Arabi.

Ahmad bin Hanbal. 1971. Al-Radd 'ala Zanadiqah wa al-Jahmiyyah. In al-Nashshar, Ali Sami' \& al-Talibi, 'Ammar Jami'. 'Aqa'id al-Salaf li al-A'immah Ahmad bin Hanbal wa al-Bukhari wa Ibn Qutaybah wa Uthman al-Darimi. Alexanderia: Munshi'ah al-Ma'arif.

al-'Aqil, Muhammad bin A. W. 2002. Manhaj Aqidah al-Shafi'i Rahimahullah. Trans. by H. Nabhani Idris. Bogor: Pustaka Imam Asy-Syafi'i.

al-Ash'ari, Abu al-Hasan. 1977. Al-Ibanah 'an Usul al-Diyanah. Ed. by Fawqiyyah Husin Mahmud. Cairo: Dar al-Ansar.

al-Ash'ari, Abu al-Hasan. 1962. Kitab al-Luma' fi al-Radd 'Ala Ahl al-Zaygh wa al-Bida'. Ed. by Richard J. Mc Carthy. Beirut: Matba'ah al-Katulikiyyah.

al-Ash'ari, Abu al-Hasan 'Ali bin Isma'il. 1950. Maqalat al-Islamiyyin wa al-Ikhtilaf al-MuSallin. Ed. by Muhammad Muhyiddin 'Abd al-Hamid. Cairo: Maktabah al-Nahdhah al-Misriyah. 
al-Ash'ari, Abu al-Hasan 'Ali bin Isma'il. 1969. Maqalat al-Islamiyyin wa al-Ikhtilaf al-Musallin. Ed. by Muhammad Muhyiddin 'Abd al-Hamid. Cairo: Maktabah al-Nahdhah al-Misriyah.

al-Athari, 'Abd Allah bin 'Abd al-Hamid. 1422H. Al-Wajiz fi 'Aqidah al-Salaf al-Salih. Saudi Arabia: Wizarah al-Shu'un wa al-Awqaf wa al-Da'wah wa al-Irshad.

al-Baqillani, Abu Bakr Muhammad bin Tayyib. 1967. Kitab al-Tamhid. Ed. by Richard J. Mc Carthy. Beirut: Maktabah al-Sharqiyyah.

Abu Hanifah 2009. Wasiyyah. In Akmal al-Din Muhammad bin Muhammad al-Babirati. Sharh Wasiyyah al-Imam Abi Hanifah. Ed. by Muhammad Subhi al-Aidi \& Hamzah Muhammad al-Bakri. Jordan: Dar al-Fath Li al-Dirasat Wa al-Nashr.

al-Bayhaqi, Abu Bakr Ahmad bin al-Hussayn. 1970. Manaqib Imam al-Syafie. 2 Vols. Cairo: Dar al-Turath. al-Bukhari, Muhammad bin Isma'il Abu 'Abd Allah. 1987. Al-Jami' al-Sahih al-Mukhtasar. Ed. by Mustafa Dib al-Bugha. Beirut: Dar Ibn Kathir.

Fath Allah Khalif. 1970. Muqaddimah Kitab al-Tawhid. In al-Maturidi. Al-Tawhid. Beirut: Dar al-Mashriq. al-Hukmi, Hafiz bin Ahmad. n.d. Ma'arij al-Qabul bi Sharh Sullam al-Wuul ila 'Ilm al-Usul fi al-Tawhid. 2 Vols. Cairo: Matba'ah al-Salafiyyah.

Ibn Asakir, 'Ali bin al-Hasan Hibbat Allah. 1347H. Tabyin Kazb al-Muftari fi Nusiba ila al-Imam Abi alHasan al-Ashari. Damascus: Matba'ah al-Tawfiq.

Ibn Hajar al-'Asqalani, Ahmad bin 'Ali. 1379H. Fath al-Bari bi Sharh Sahih al-Bukhari. 13 Vols. Beirut: Dar al-Ma'rifah.

Ibn Kathir, Abu al-Fida'. 1966. Al-Bidayah wa al-Nihayah. 14 Vols. Beirut: Maktabah Dar al-Ma'arif.

Ibn Manzur, Jamal al-Din Abu al-Fadl Muhammad bin Mukarram. n.d. Lisan al-Arab. Cairo: Dar alMa'arif.

Ibn Taymiyyah, Abu al-'Abbas Ahmad. 1321H. Minhaj al-Sunnah al-Nabawiyyah fi al-Naqd Kalam alShi'ah wa al-Qadariyyah. 4 Vols. Cairo: Matbaah al-Kubra al-Amiriyyah.

Ibn Taymiyyah, Ahmad bin 'Abd al-Halim. 1999. Naqd al-Mantiq. Ed. by Muhammad bin Abd al-Razzaq. Beirut: Dar al-Kutub al-'Ilmiyyah.

McCarthy, Richard J. 1953. The Theology of al-Ash'ari. Beirut: Impremerie Catholic.

al-Misri, Muhammad 'Abd al-Hadi. 1992. Ahl al-Sunnah wa al-Jama'ah: Ma'alim al-Intilaqat al-Kubra. Cairo: Dar al-I'lam al-Duwali.

Mohd Sulaiman Yassin. 1997. Aqidah Muslim. 2 Vols. Bangi: Yayasan Salman.

Mustafa al-Ghurabiyy. n.d. Tarikh al-Firaq al-Islamiyyah. Cairo: Matba'ah Muhammad Ali Subigh.

al-Nashshar. 1977. Nash'ah al-Fikr al-Falsafi fi al-Islam. 3 Vols. 7th ed. Cairo: Dar al-Ma'arif.

Salum, Muhammad bin 'Ali. 1966. Lawami' al-Anwar al-Bahiyyah wa Sawati' al-Asrar al-Athriyyah: Sharh al-Durrah al-Mudi'ah fi 'Aqd al-Firaq al-Mardiyyah. Ed. by Muhammad Zuhri al-Najjar. np.: n.p.

al-Safarayni, Muhammad bin Ahmad. n.d. Lawami' al-Anwar al-Bahiyyah wa Sawati' al-Asrar al-Athriyyah (Makhtut). 2 Vols. n.p: n.p.

al-Shahrathani. 1968. Al-Milal wa al-Nihal. Ed. by 'Abd al-'Aziz Muhammad al-Wakil. 4 Vols. n.p.: Muassasah al-Halabi.

al-Subki, Abu Nasr 'Abd al-Wahhab bin 'Ali bin 'Abd al-Kafi. 1918. Tabaqat al-Shafi'iyyah al-Kubra. Vol. 3. Cairo: Dar Ihya' al-Kutub al-'Arabiyyah.

al-Subki, Abu Nasr Abdul Wahhab bin 'Ali bin 'Abd al-Kafi. 1964. Tabaqat al-Shafi'iyyah al-Kubra. Ed. by 'Abd al-Fatah Muhammad al-Halw \& Mahmud Muhammad al-Tahani. 8 Vols. Cairo: Matba'ah 'Isa al-Babi al-Halabi.

al-Tabari, Ibn Jarir. 2009. Jami' al-Bayan 'an Ta'wil Ay al-Qur'an: Tafsir al-Tabari. Trans. by Fathurrozi et al. Jakarta: Pustaka Azam. 